\title{
Determination of Mass
}

Balance and Entrainment

in the Stratified

Duwamish River Estuary,

King County, Washington

GEOLOGICAL SURVEY WATER-SUPPLY PAPER 1873-F

Prepared in cooperation with the Municipality of Metropolitan Seattle

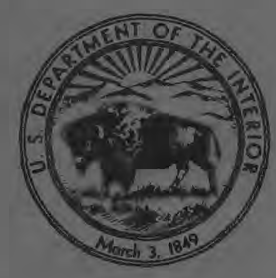




\section{Jetermination of Mass}

3alance and Entrainment

in the Stratified

Juwamish River Estuary,

Zing County, Washington

By J. D. STONER

ENVIRONMENTAL QUALITY

FEOLOGICAL SURVEY WATER-SUPPLY PAPER 1873-F

Prepared in cooperation with the

Municipality of Metropolitan Seattle

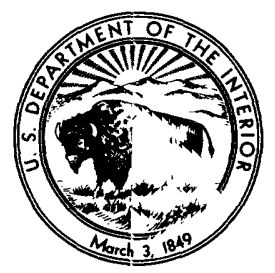




\section{UNITED STATES DEPARTMENT OF THE INTERIOR}

ROGERS C. B. MORTON, Secretary

\section{GEOLOGICAL SURVEY}

V. E. McKelvey, Director

Library of Congress catalog-card No. 72-600253

For sale by the Superintendent of Documents, U.S. Government P rinting Office Washington, D.C. 20402 - Price 30 cents (paper cover) Stock Number 2401-00252 


\section{CONTENTS}

$\begin{array}{lr}\text { Introduction } & 1 \\ \text { Description of the estuary } & 3 \\ \text { Tides } & 3 \\ \text { Salinity } & 5 \\ \text { Methods and equipment } & 10 \\ \text { Malinity and velocity studies } & \\ \text { Entrainment velocity } & 16 \\ \text { Summary and conclusions } & \\ \text { Selected references }\end{array}$

\section{ILLUSTRATIONS}

Figure 1. Map of Duwamish River estuary

2. Longitudinal profile of the Duwamish River estuary ----

3. Graph showing cross-sectional area of the Duwamish River estuary

4. Generalized longitudinal diagram of part of the Duwamish River estuary, showing idealized conditions of water movement and entrainment

5. Diagrammatic cross section at 16 th Avenue South Bridge

6-8. Graphs showing vertical salinity profiles at 16 th Avenue South Bridge for maximum and minimum tide stages:

6. August 28-29, 1967

7. September 6-7, 1967 _-_-_- 10

8. May 22-23, 1968 _._-_-__- 11

9. Graph showing measured flow rates for upper and bottor layers, and for total cross-sectional area, at $16 \mathrm{tr}$ Avenue South Bridge 


\title{
DETERMINATION OF MASS BALANCE AND ENTRAINMENT IN THE STRATIFIED DUWAMISH RI'ER ESTUARY, KING COUNTY, WASHINGTON
}

\author{
BY J. D. STONER
}

\begin{abstract}
During a study of the effects of waste-water input on the stratified Duwamish River estuary, intensive water-velocity and salinity measurements were made in both the lower salt wedge and the upper fresher water layer for tidal-cycle periods. The net movement of water and salt mass past a cross section during a tidal cycle was determined from integration of the measured rates of movement of water and salt past the section. The net volume of water that moved downstream past the section during the cycle agreed with the volume of fresh-water inflow at the head of the estuary within (1) 3.8 and 7.2 percent, respectively, for two studies made during periods of maximum and minimum tidal-prism thickness and identical inflow rates of $312 \mathrm{cfs}$ (cubic feet per second), and (2) 15 percent for one study made during a period of average tidal-prism thickness and an inflow rate of $1,280 \mathrm{cfs}$. For the three studies, the difference between salt mass transported upstream and downstream during the cycles ranged from 0.8 to 19 percent of the respective mean salt-mass transport. Water was entrained from the salt-water wedge into the overlying layer of mixed fresh and salt water at tidal-cycle-average rates of 30 and $69 \mathrm{cfs}$ per million square feet of interface for the inflow rates of $312 \mathrm{cfs}$, and $99 \mathrm{cfs}$ per million square feet of interface for an inflow rate of $1,280 \mathrm{cfs}$. At a constant inflow rate, the rate of entrainment of salt-wedge water in the Duwamish River ertuary more than doubled for a doubling of tidal-prism thickness. It also doubled for a quadrupling of inflow rate at about constant tidal-prism thickness.
\end{abstract}

\section{INTRODUCTION}

A comprehensive investigation of the Duwamish River estuary is being made by the U.S. Geological Survey in cooperation with the Municipality of Metropolitan Seattle (Metro) to evaluate the changes that take place in the estuary as a result of changes in 
the quantity and type of waste being discharged ir to the estuary. The purpose of this phase of the study is to develop a better understanding of the rate that the saline water (salt-water wedge) flowing into the estuary from Elliott Bay entrains into the river water containing the Renton Treatment Plant effluent. The part of the estuary under study extends from the mouth of the estuary at Elliott Bay to Renton Junction, approximately 13.1 river miles upstream (fig. 1). Prior to 1969 several sewage out-

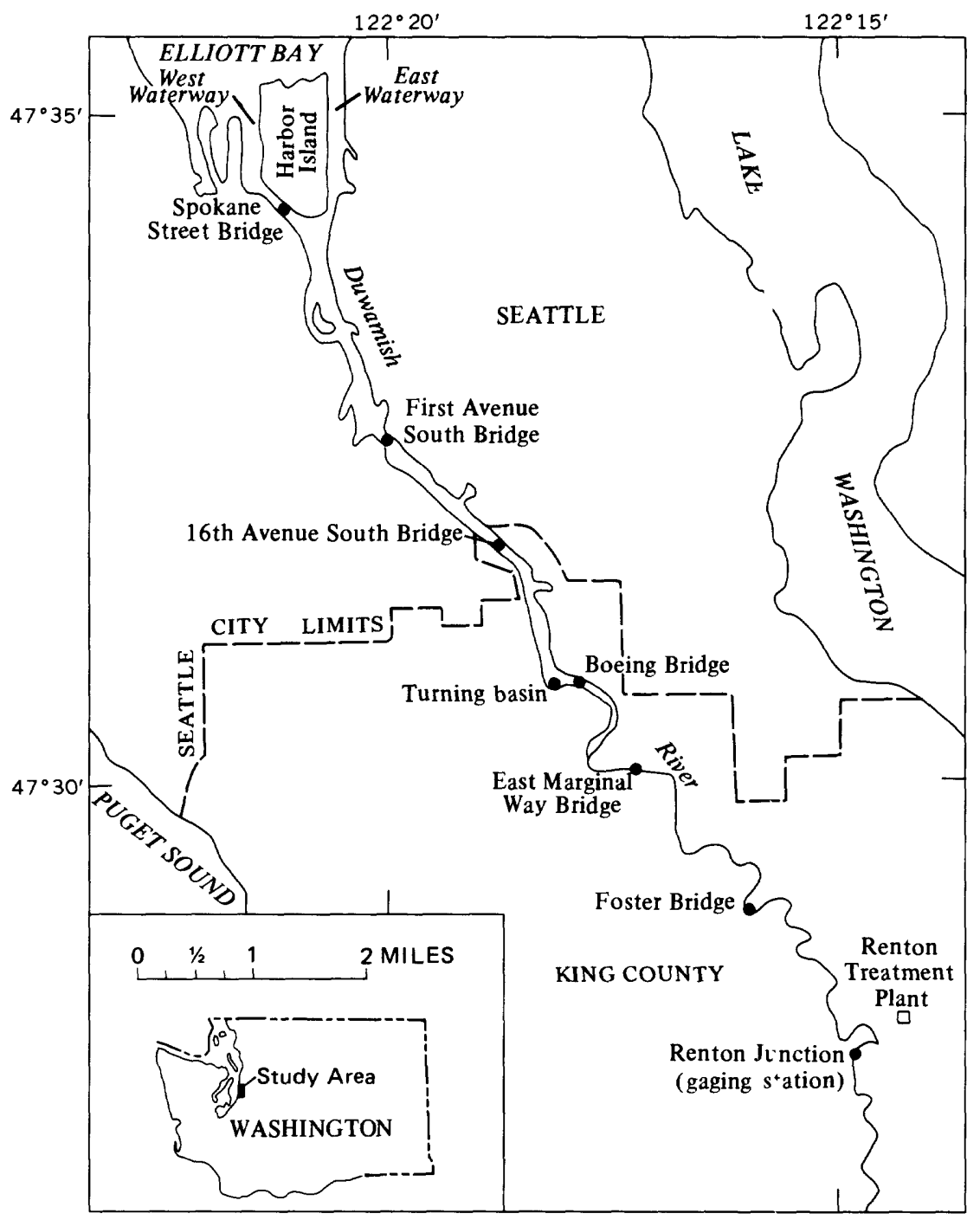

FIGURE 1.-Duwamish River estuary and data-collecticn sites. 
falls existed in the study reach; since then Metro's interceptor sewer has eliminated all except a few minor waste-water outfalls, and the only sizable sewage discharge to the study reach is the treated effluent from Metro's Renton Treatment Plant (fig. 1). A major objective of the comprehensive investigation is to determine the effects of this treated effluent on the estuary.

Other phases of the comprehensive investigation of the estuary, but beyond the scope of this report, include estuary ecology and the physical, chemical, and biochemical characteristics of the fresh and saline water. (See "Selected References.")

\section{DESCRIPTION OF THE ESTUARY}

The bottom of the estuary ehannel ranges from about 5 feet above MLLW (mean lower low water; see "Tides") at Renton Junction, 13.1 miles above the mouth of the estuary, to 38 feet below MLLW at Spokane Street Bridge, 1.2 miles above the mouth (fig. 2). The estuary channel downstream from the turning basin (fig. 1), which is 6.1 miles above the mouth, is dredged in stairstep fashion, being progressively deeper downstream. The turning basin is the upstream limit of navigation for all but small boats.

The cross-sectional area of the estuary channel decreases upstream approximately exponentially (fig. 3). Cross-sectional areas in the reach from Renton Junction to East Marginal Way Bridge, 7.8 miles above the mouth, are generally less than 1,000 square feet, whereas cross-sectional areas in the widest reach of the lower part of the estuary exceed 30,000 square feet.

The estuary is divided near the mouth into the East and West Waterways. The East Waterway is closed to upstream navigation by pilings set at the southeast end of Harbor Island. Flow measurements have shown that about 80 percent of the flow passes through the West Waterway.

\section{TIDES}

The tides in the Duwamish River estuary are semidiurnal, with marked inequalities in the successive high- or low-tvater stages. This diurnal inequality necessitates the designation of a higher high water (HHW), a higher low water (HLW), a lower high water (LHW), and a lower low water (LLW) during each complete tidal cycle of about 25 hours. The datum plane for tide height in the Duwamish River estuary is mean lower low water (MLLW) at a tide reference station about 1 mile northerst of the estuary mouth; this station is maintained by the U.S. Environmental Science Services Administration. Mean lower low 


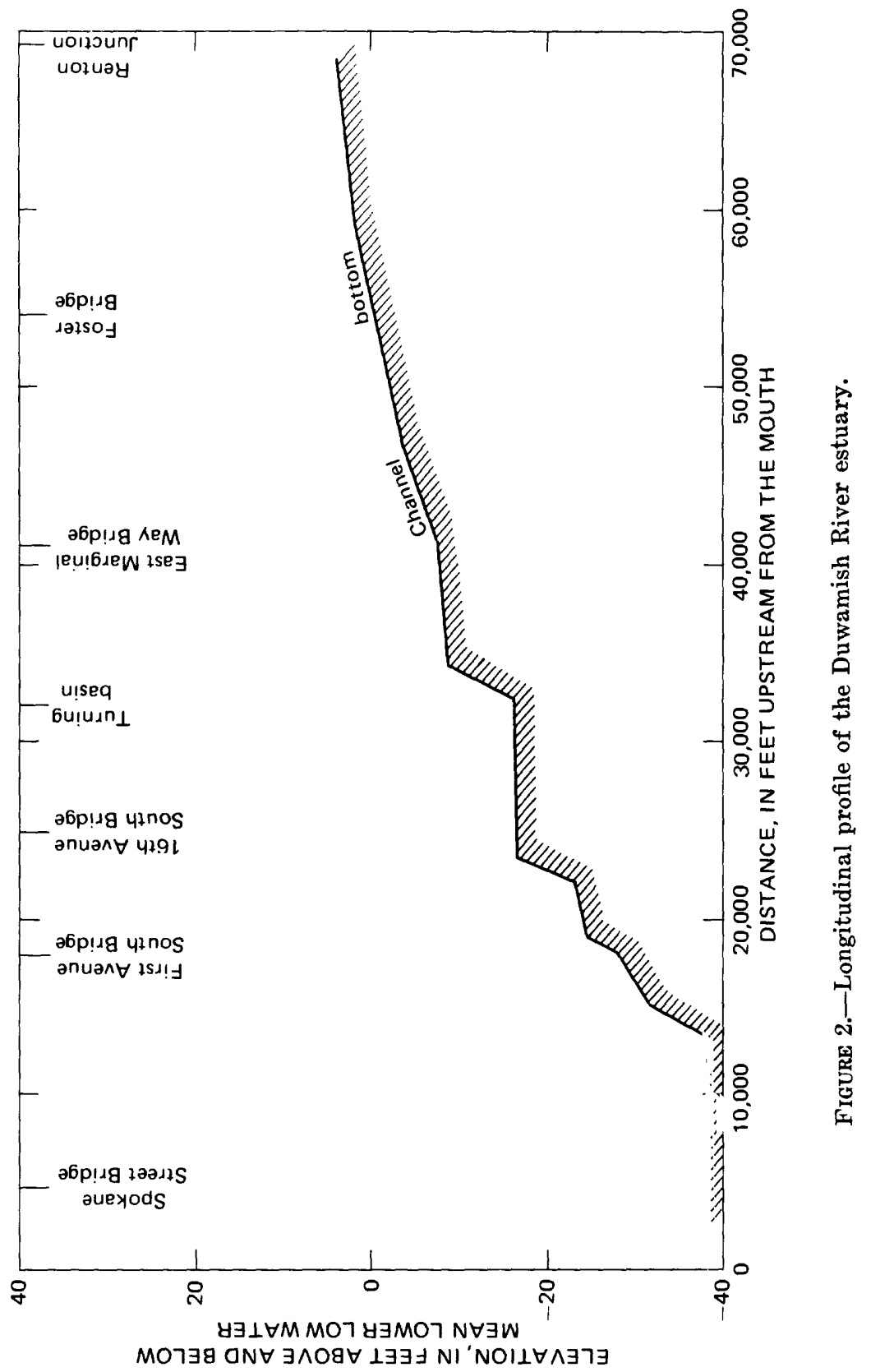




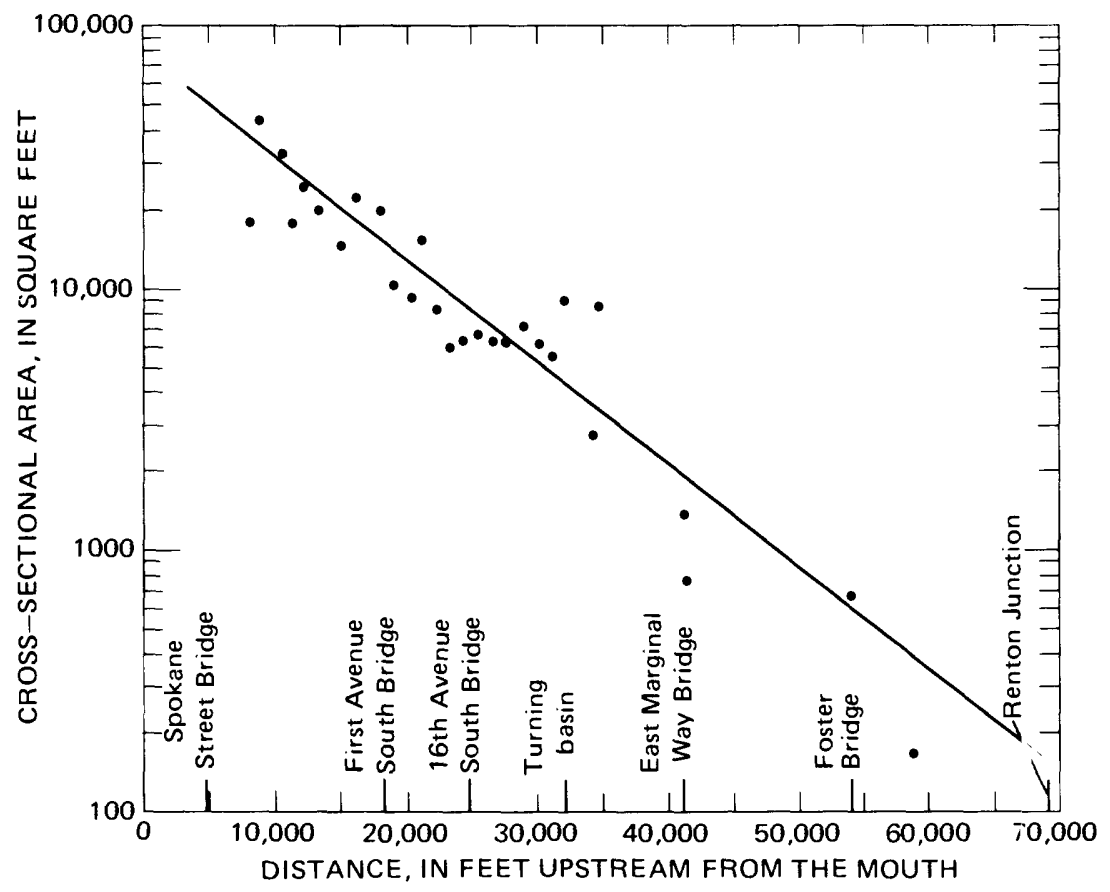

FiguRE 3.-Cross-sectional area of the Duwamish River estuary at 7.2 feet above mean lower low water.

water is the average of the lower low-water levels. Mean tide stage is 6.6 feet above MLLW, and maximum and minimum recorded stages are 14.7 feet above MLLW and 4.6 feet below MLLW, respectively. These data were obtained from the U.S. Environmental Science Services Administration (1967, p. 174).

\section{SALINITY}

Circulation of water within a stratified estuary comprises a net upstream movement of water within a lowermost salt-water wedge and a net downstream movement of fresher water in the layer overriding the wedge (fig. 4) (Pritchard, 1955). The saline wedge water, which has its source in Elliott Bay, oscillates upstream and downstream with the tide. During periods of low fresh-water inflow and high tide stage the salt-water wedge has extended upstream as far as the Foster Bridge, 10.2 miles above the mouth. At fresh-water inflow greater than 1,000 cfs (cubic feet per second) the salt-water wedge does not extend upstream beyond East Marginal Way Bridge regardless of tide loight (Stoner, 1967). 


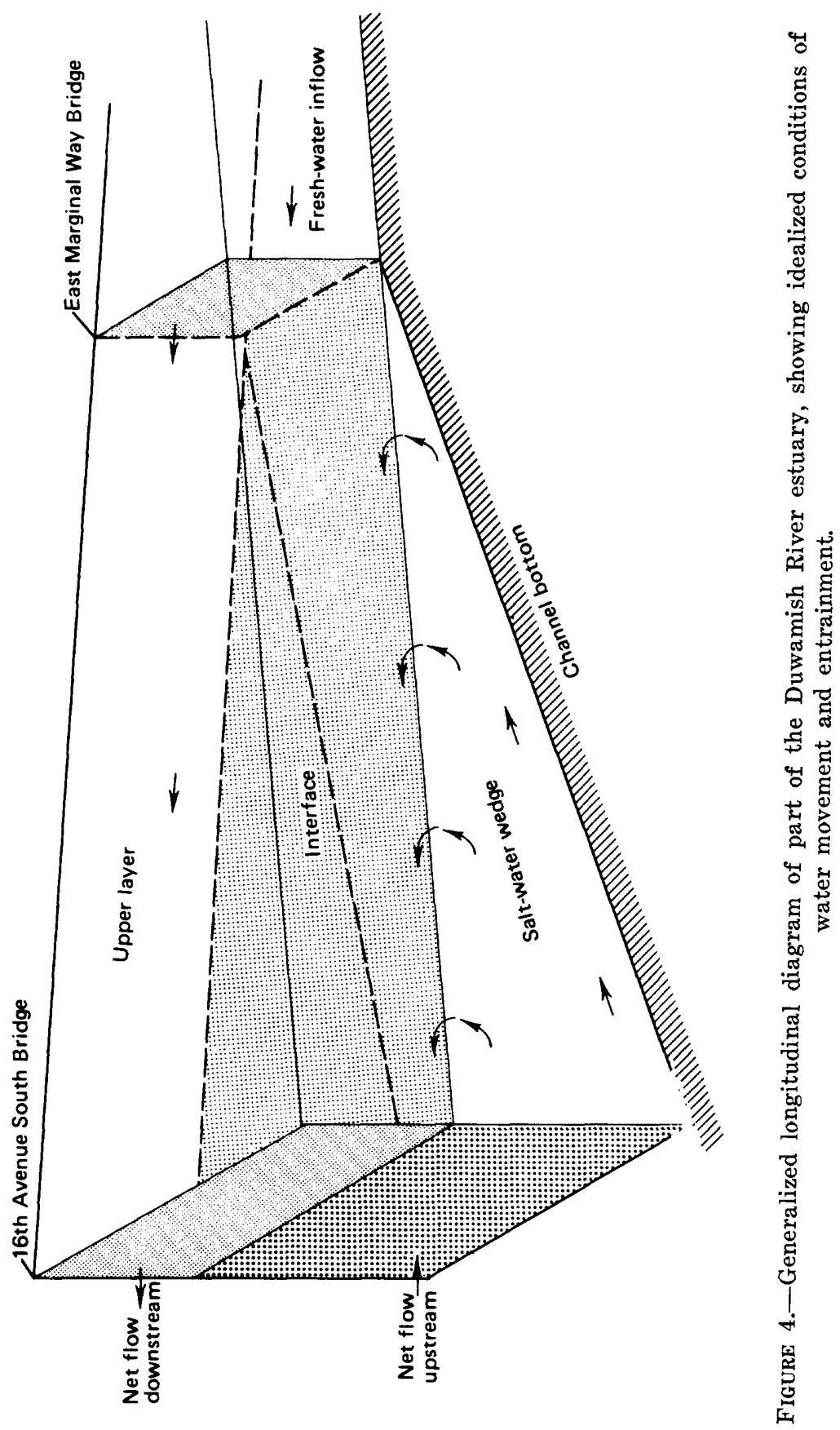


Saline water from the wedge is entrained in the overriding layer of fresher water at the interface between the two. There is little or no downward movement of water from the upper layer into the salt-water wedge; studies using fluorescent dye have shown that downward mixing in the stratified estuary is negligible (Santos and Stoner, 1972). Also, at any given time and location along the estuary, the salinity concentration at a given depth is nearly the same from one side of the channel to the other.

\section{METHODS AND EQUIPMENT}

The determination of the distribution of fresh water (and its contained pollutants) by the concurrent measurement of velocity and salinity profiles at many flow sections is impractical even in a small estuary like the Duwamish. Therefore, the approach in this study utilizes net changes in discharge and salinity over specific tidal cycles in a reach of the estuary where bourdary conditions and inflow and outflow can be closely defined. Three salinity-velocity studies at a selected cross section in the estuary were made to determine whether the mass balance for water and salt could be calculated from field measurements. If mass balance, particularly in the case of water volume, could be closely apr roximated from field data, then a fairly valid rate of entrainment of saline water into the upper layer could be determined.

The 16th Avenue South Bridge, 4.8 miles upstream from the estuary mouth, was chosen as the site for the salinity-ve!ocity studies. Velocities were measured with current meters from the bridge, while direction of flow was measured with a vane attached to a pointer which was free to pivot about the cable from which the current meter was suspended. Velocity and direction of flow were measured simultaneously always at two verticals in the main channel, and at an additional vertical on each side of the channel only during periods of maximum velocity. Velocity and direction of flow were measured just below the water surface and at every tenth of the depth to the channel bottom. The angle of direction of flow was measured relative to the bridge.

Salinity and temperature were measured with an electrodeless induction salinometer. Because the salinity is laterally uniform, it and temperature were measured only at midstream. These parameters were measured just below the surface and at every 1.5 feet of depth. Measurements were made from a small boat in order to facilitate the handling of the salinometer cable. Velocity, flow direction, salinity, and temperature were measured every half hour, except at the side verticals where flow velocity 
and direction were measured at hourly intervals during the periods of higher velocity. All the field studies were continued for a minimum of 26 hours to insure the obtaining of data during a complete tidal cycle.

Prior to any fieldwork, a water-stage recorder was installed on a fender at the 16th Avenue South Bridge. The stage recorder established the changes in tide stage, which were used to calculate changes in cross-sectional area. Before the initial study, the channel cross section at the site was measured accurately and plotted with the depth scale referenced to MLLW (fig. 5).

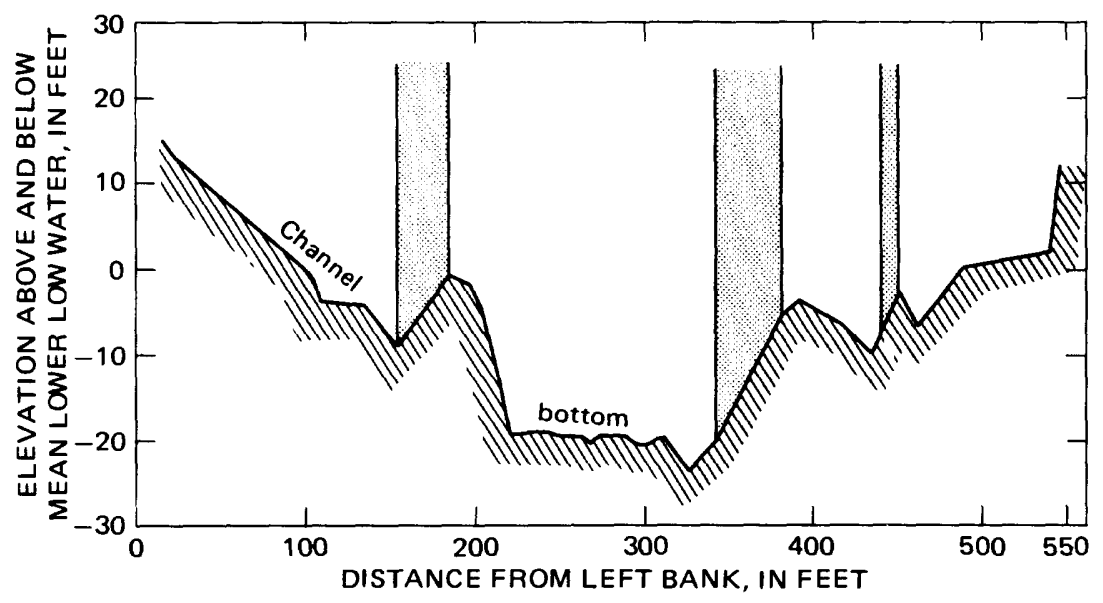

FIgURE 5.-Diagrammatic cross section at 16th Avenue South Bridge. Shaded areas are bridge piers.

\section{SALINITY AND VELOCITY STUDIES}

The initial salinity-velocity study was made on August 28-29, 1967, when tidal exchange was small and the rate of fresh-water inflow was low. The tidal exchange was indicated by the tidalprism thickness (sum of the high tides minus the sum of the low tides over a tidal cycle), which was 10.2 feet. Minimum tidalprism thickness in the Duwamish River estuary during the year is about 9.5 feet, whereas the maximums range from 18 to 21 feet. Average fresh-water inflow during the 2-day period was $312 \mathrm{cfs}$, which is in the low-inflow range for the estuary.

The vertical salinity profiles taken during the study showed that the salt-water wedge was fairly well developed even during this period of low tidal exchange and fresh-water inf'ow. Vertical salinity profiles, at times of maximum and minimum tide stage, 
are shown in figure 6 . The depth to the interface between the salt wedge and the upper layer was determined for each of the one-half-hourly measurements, by inspection of the respoctive vertical salinity, temperature, and velocity profiles. The top of the wedge was generally delineated at the depth where the rate of change in the salinity profile (measuring upward) became g:eater than about 1 ppt (parts per thousand) per 3 feet of depth. (See fig. 6 for example.) The salinity concentration at the interface varied slightly and the average was $24.5 \mathrm{ppt}$. The salinity of the wedge water remained fairly constant during this study (fig. 6) and averaged about $27.5 \mathrm{ppt}$.

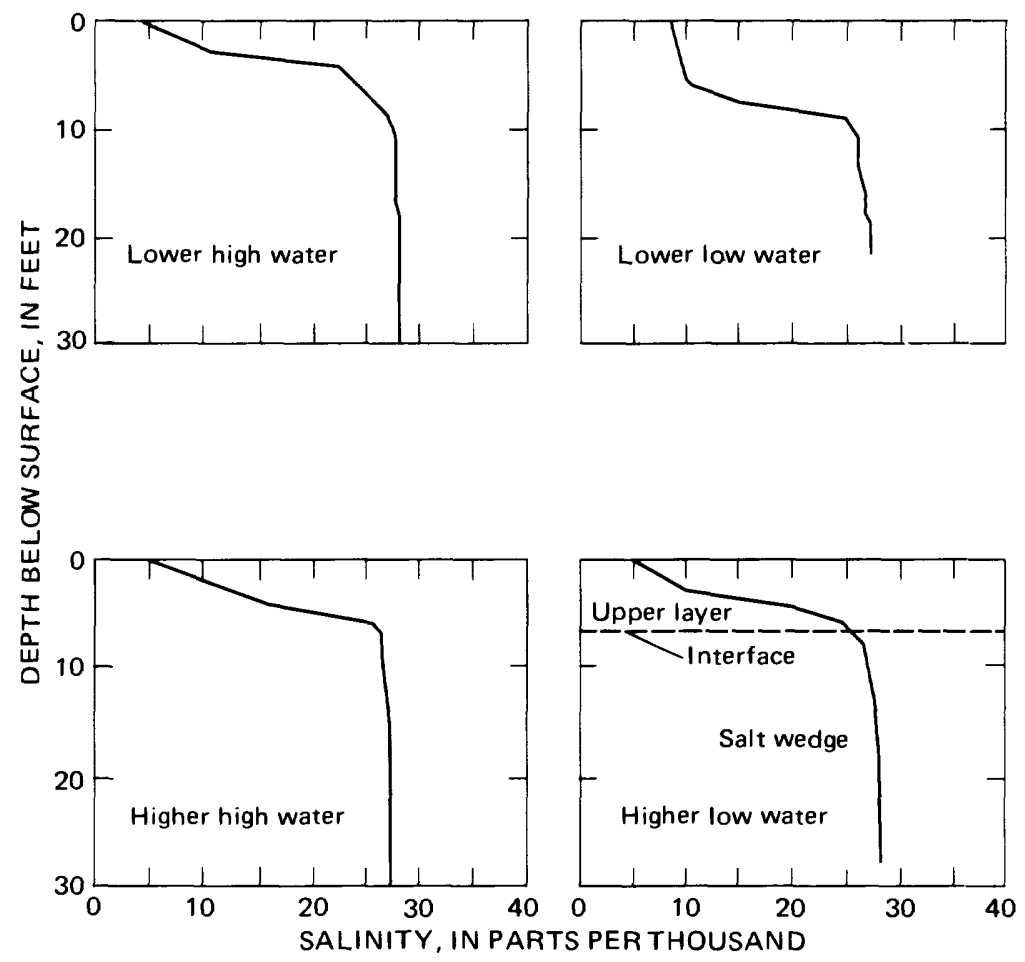

Figure 6.-Vertical salinity profiles at 16 th Avenue South Bridge for maximum and minimum tide stages, August 28-29, 1967.

The second salinity-velocity study was made during September $6-7,1967$. The average fresh-water inflow during the stuc'y was $312 \mathrm{cfs}$, the same as that of the initial study; the significant difference in conditions between the studies was the tidal exchange. The tidal-prism thickness of 20.6 feet was near maximum and 
was 10.4 feet thicker than the tidal prism during the initial study. Vertical salinity profiles (fig. 7) show that the wedge was reasonably well developed. The average salinity at the interface for this study was $23.0 \mathrm{ppt}$, and the mean salt-wedge salinity was 25.8 ppt.

The third salinity-velocity study was made on May 22-23, 1968. The tidal exchange was 14.7 feet, which was near the mean 15.2 feet, and the fresh-water inflow was $1,280 \mathrm{cfs}$. Definition of the salt-water wedge and interface throughout this study was very good (fig. 8). The average salinity was $24.1 \mathrm{ppt}$ at the interface and $26.9 \mathrm{ppt}$ in the salt wedge.

\section{MASS BALANCE}

The principle of continuity, or mass conservation, requires that, at the steady state, net mass advected upstream of a given point in the estuary must equal the net mass advected downstream of the point. The principle holds for either water mass or salt mass.

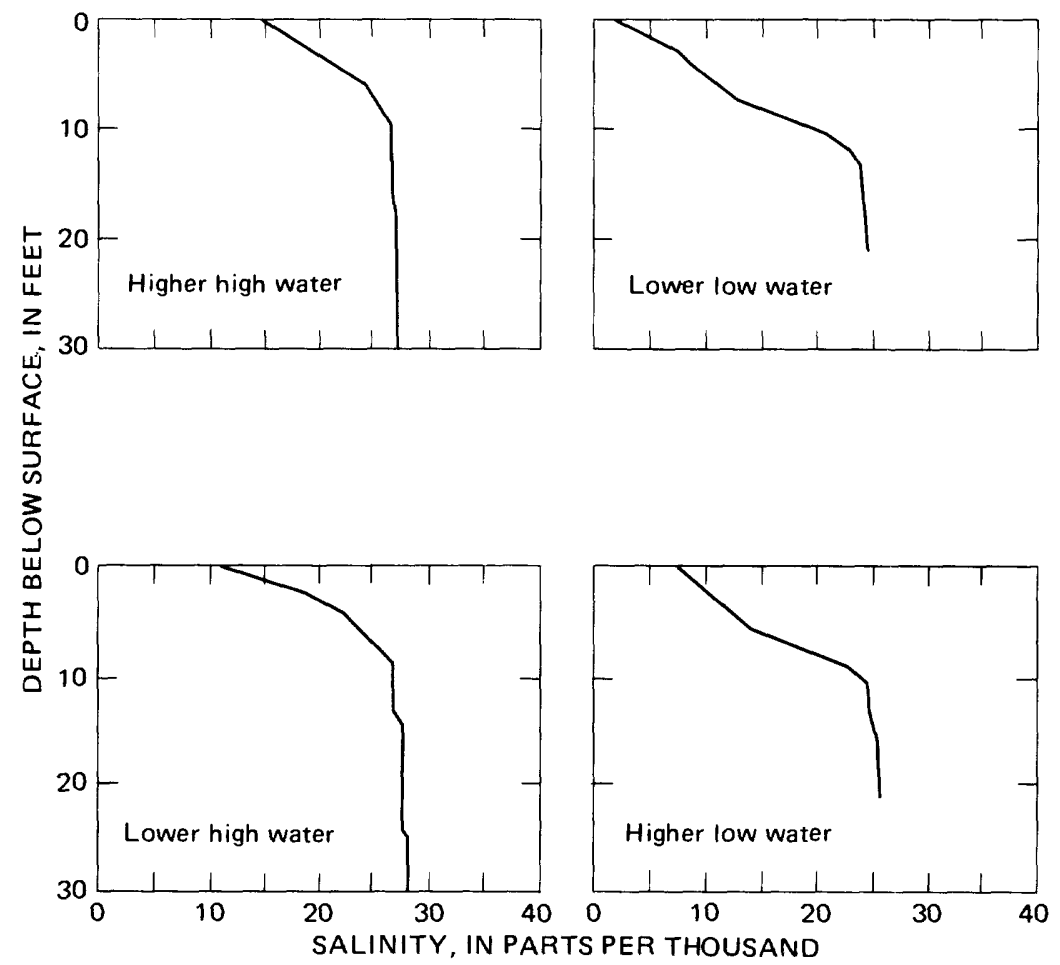

Figure 7.-Vertical salinity profiles at 16th Avenue South Bridge for maximum and minimum tide stages, September 6-7, 1967. 


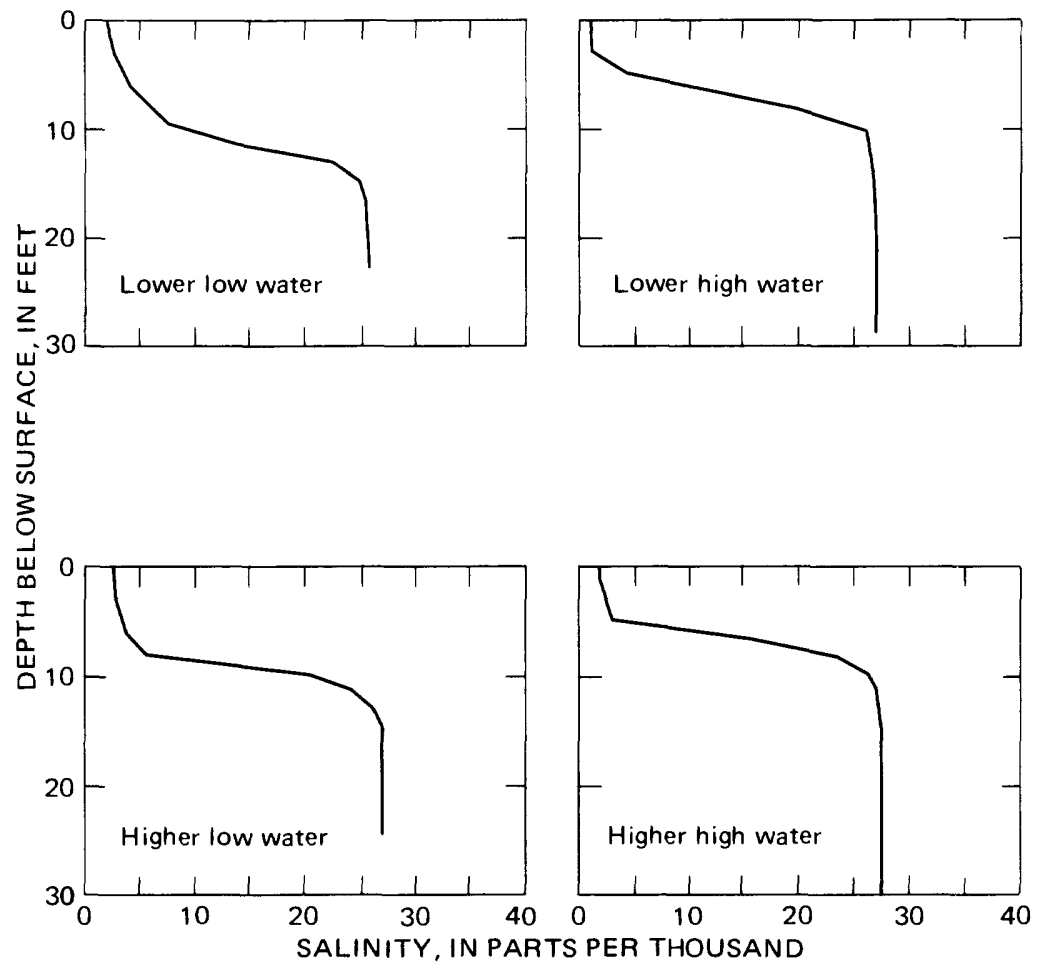

Figure 8.- Vertical salinity profiles at 16th Avenue South Bridge for maximum and minimum tide stages, May 22-23, 1968.

Because the estuary is of the salt-water wedge type and essentially a two-layer system, it may be assumed that net upstream advection occurs in the bottom layer and net downstream advection occurs in the upper layer. The following mathematical statements show the net salt- and water-mass balance at a cross section:

$$
S_{b}+S_{u}=0
$$

and

$$
Q_{b}+Q_{u}=Q_{f}
$$

where

$S_{b}=$ net salt mass advected in the bottom layer,

$S_{u}=$ net salt mass advected in the upper layer,

$Q_{b}=$ net water mass advected in the bottom layer,

$Q_{u}=$ net water mass advected in the upper layer, and

$Q_{f}=$ fresh-water inflow. 
All transports (advections) are defined positive downstreamwise at the cross section. $Q_{f}$ is always nonnegative.

To approximate steady-state conditions in the Duwamish River estuary, a time period over approximately one tidal cycle was chosen. A tidal cycle is short enough to allow field measurements and, also, flow, stage, and other conditions in the estuary at the beginning and ending of the cycle may agree closely enough to reasonably approximate a steady-state condition. The boundary condition that required satisfaction is that the water elevations within the estuary at the beginning of the study period (a tidal cycle) were equal to the water elevations at the end of the period. When this boundary condition is satisfied, water-mass balance is achieved. As for salt-mass balance, the boundary condition is that the salinity at every point in the reach is equal at the beginning and at the end of the study period. It is difficult to ascertain this condition in the estuary, thus salt-mass balance as observed may not be as exact as in the mathematical expression, equation 1 .

The analysis of the water-mass balance was developed as follows: The computed flow rates for the three studies were plotted against time as in figure 9. A quasi-steady-state period, T, was chosen using the boundary conditions stated previously for each of the three studies. The areas under the upper-layer, bottomlayer, and total-flow curves were then planimetered over the period $T$ to determine the total volume of water that moved through each of the layers and through the section. Fresh-water inflow to the system was determined from the relation between recorded stage and discharge at Renton Junction (fig. 1). In addition to this inflow, $35 \mathrm{cfs}$ was added to account for the discharge from the Renton Treatment Plant and minor urgaged inflow between the stage-recorder site and the cross section where salinity and velocity were measured.

The following table shows the values calculated from the field studies for the water-mass balance.

\begin{tabular}{|c|c|c|c|c|c|c|}
\hline \multirow[t]{2}{*}{ Date } & \multirow{2}{*}{$\begin{array}{c}\text { Quasi- } \\
\text { steady-state } \\
\text { period, } T \\
\text { (thousands } \\
\text { of sec) }\end{array}$} & $\begin{array}{c}\text { Bottom- } \\
\text { layer } \\
\text { outflow, } \\
Q b \\
\end{array}$ & $\begin{array}{c}\text { Upper- } \\
\text { layer } \\
\text { outflow, } \\
Q_{u}\end{array}$ & $\begin{array}{c}\text { Total } \\
\text { net } \\
\text { outflow, } \\
Q_{t}\end{array}$ & $\begin{array}{c}\text { Fresh- } \\
\text { water } \\
\text { inflow, } \\
Q_{f}\end{array}$ & \multirow{2}{*}{$\begin{array}{c}\begin{array}{c}\text { Percentage } \\
\text { error, }\end{array} \\
\frac{\left(Q_{t}-Q_{f}\right) 100}{Q_{f}}\end{array}$} \\
\hline & & \multicolumn{4}{|c|}{ Millions of cubic feet } & \\
\hline $\begin{array}{l}\text { Aug. } 28-29,1967 \\
\text { Sept. } 6-7,1967,-- \\
\text { May 22-23, } 1968 \text {--- }\end{array}$ & $\begin{array}{l}85.0 \\
83.4 \\
84.0\end{array}$ & $\begin{array}{l}-11.5 \\
-21.7 \\
-15.1\end{array}$ & $\begin{array}{l}39.9 \\
47.7 \\
139\end{array}$ & $\begin{array}{l}28.4 \\
27.0 \\
124\end{array}$ & $\begin{array}{l}26.5 \\
26.0 \\
108\end{array}$ & $\begin{array}{l}7.2 \\
3.8 \\
15\end{array}$ \\
\hline
\end{tabular}

The negative quantities calculated for $Q_{b}$ show that net watermass movement in the bottom layer is, in fact, in the upstream 


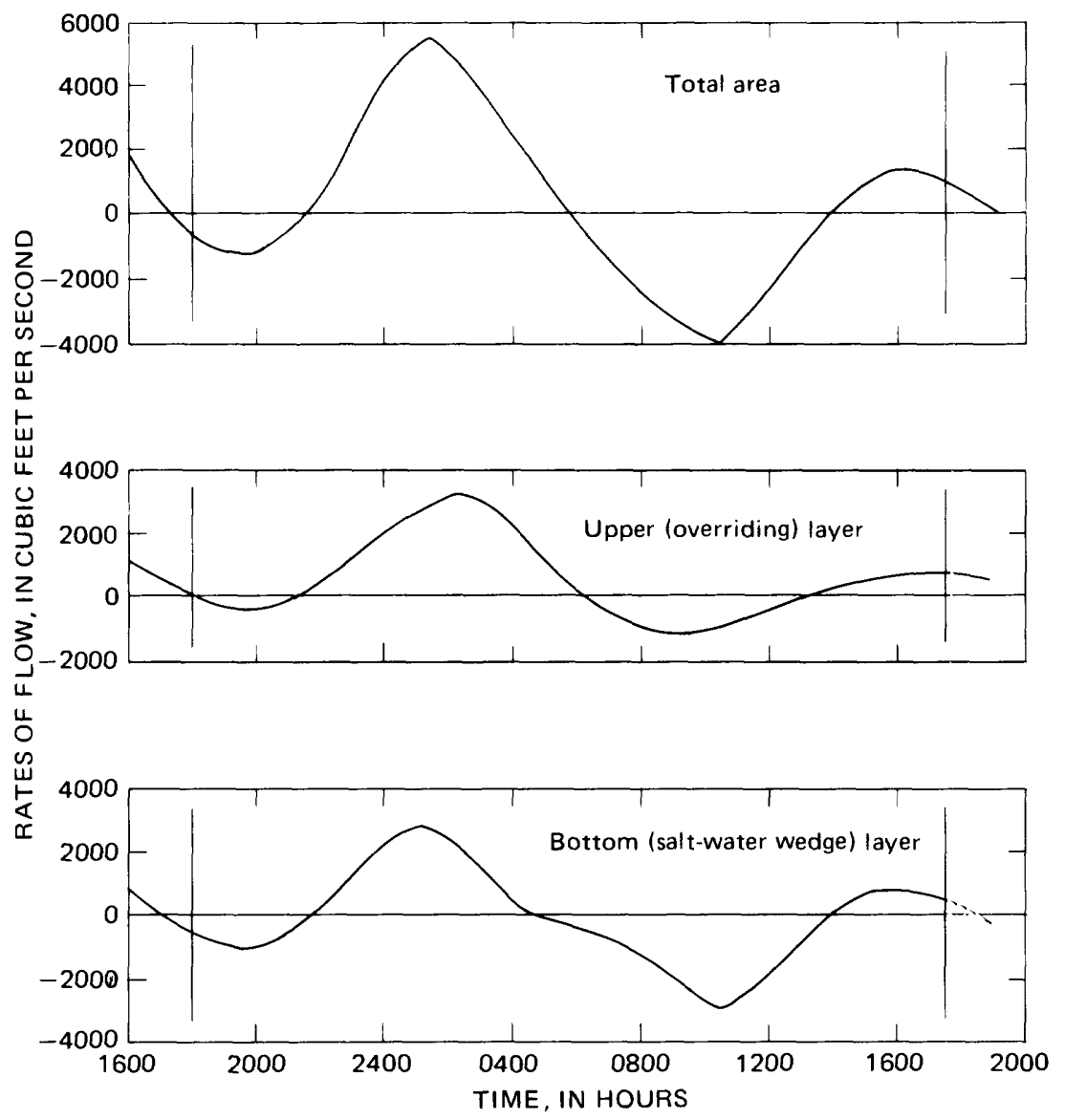

Figure 9.-Measured flow rates for upper and bottom layers, and for total cross-sectional area, at 16 th Avenue South Bridge, from $160 \mathrm{C}$ hours August 28 to 1900 hours August 29, 1967. Negative flow rates indicate upstream flow. The vertical bars represent the times of equal tide height used to define the period analyzed.

direction. Conversely, the positive quantities for $Q_{u}$ ind cate a downstream direction for net water-mass movement in the upper layer. These calculations from field measurements serve to prove that water circulation within the estuary closely approrimates that described on page F5, and in figure 4.

The measured values verify the requirement that, under steadystate conditions, the volume of fresh water entering the estuary must equal the net volume of mixed (fresh plus saline) water moving downstream past the measuring section. Inasmuch as the algebraic sum of $Q_{u}$ and $Q_{b}$ equals the net water mass moved 
downstream past the section $\left(Q_{t}\right)$, or

$$
Q_{u}+Q_{b}=Q_{t}
$$

then, substituting from equation 2 ,

$$
Q_{f}=Q_{t}
$$

The measured values for net water-mass movement past the measuring section, $Q_{t}$, were all greater than the fresh-water inflow, $Q_{f}$. However, the differences between the measured $Q_{t}$ and the actual $Q_{f}$ were not so large as to invalidate the use of results of these measurements as reasonable estimates of water-mass balance within the estuary.

Salt-mass balance within the estuary was calculated in much the same manner as the water-mass balance. That is, the measured values of net water-mass movement, $Q_{u}$ and $Q_{b}$, and the measured mean values of salinity in the upper and lower layers, $C_{u}$ and $C_{b}$, were used to develop values for the net wreight of salt moved past the measuring section during the study periods. Because the salinity of the inflowing river water is essontially zero, combining equations 1 and 2 yields

$$
\left(Q_{f}\right)(0)=\left(Q_{b}\right)\left(C_{b}\right)+\left(Q_{u}\right)\left(C_{u}\right)
$$

or

$$
S_{b}+S_{u}=0
$$

where $S_{b}=\left(Q_{b}\right)\left(C_{b}\right)$ and $S_{u}=\left(Q_{u}\right)\left(C_{u}\right)$. Because the salt-mass movement is dependent upon the measured water-mass movement, any errors in salinity would be superimposed upon the errors in the water-mass balance. Also, as previously stated (p. F12), the relative volumes of the upper and bottom layers might be different at the beginning and end of the study periods. Therefore, the salt-mass balance was not expected to be as accurate as the water-mass balance. Salt-mass balance was determined from integration of plotted curves of the rates of salt

\begin{tabular}{|c|c|c|c|c|c|}
\hline \multirow[t]{2}{*}{ Date } & \multirow[t]{2}{*}{$\begin{array}{c}\text { Quasi-steady- } \\
\text { state period, } T \\
\text { (thousands of sec) }\end{array}$} & $\begin{array}{l}\text { Salt transport } \\
\text { in the upper } \\
\text { layer, } S_{u}\end{array}$ & $\begin{array}{c}\text { Salt transport } \\
\text { in the bottom } \\
\text { layer, } S_{b}\end{array}$ & \multirow{2}{*}{$\begin{array}{l}\text { Difference } \\
\text { (millions of } \\
\text { pounds) }\end{array}$} & \multirow{2}{*}{$\begin{array}{l}\text { Percentage } \\
\text { error of } \\
S_{u} \text { and } S_{b}\end{array}$} \\
\hline & & \multicolumn{2}{|c|}{ Millions of pounds } & & \\
\hline $\begin{array}{l}\text { Aug. } 28-29,1967 \\
\text { Sept. } 6-7,1967 \\
\text { Aug. } 22-23,1968\end{array}$ & $\begin{array}{l}85.0 \\
83.4 \\
84.0\end{array}$ & $\begin{array}{r}106 \\
236 \\
92\end{array}$ & $\begin{array}{l}-117 \\
-238 \\
-111\end{array}$ & $\begin{array}{r}11 \\
2 \\
19\end{array}$ & $19^{.8}$ \\
\hline
\end{tabular}
movement in the upper and lower layers during the study periods. The resulting transport of salt at the section are shown in the following table. 
The percentage differences in the table were determined by comparing the difference values to the average of the correspcnding products, $Q_{u} C_{u}$ and $Q_{b} C_{b}$, inasmuch as there was no way of knowing which of those products more closely approximated the actual salt transport. The negative quantities of $S_{b}$ in the table indicate upstream transport of salt mass in the wedge.

The magnitude of the percentage error in salt-mass balance corresponds reasonably well with the magnitude of the percentage error in water-mass balance.

\section{ENTRAINMENT VELOCITY}

Because of the reasonable balance of salt and water masses that were determined from the field measurements, it can be assumed that the volume of wedge water that is entrainet into the upper layer during the quasi-steady-state period is equal to the water mass that is moved upstream in the bottom layer during that period. The rate of entrainment obviously is not constant throughout the period, but definition of instantaneous ertrainment rates by using these data is not feasible. However, the average rate of upstream water-mass movement of the bottom layer can be used with reasonable confidence to compute an average rate of entrainment of salt-wedge water during a tidal-cycle study period.

For the computation of the entrainment velocity, two assumptions were made. The first, which was reinforced by field data, was that at fresh-water inflow rate of $312 \mathrm{cfs}$ the mean location of the toe (upstream end) of the salt wedge would be at East Marginal Way Bridge, and at fresh-water inflow of $1,280 \mathrm{cfs}$ the mean location of the toe would be at Boeing Bridge (fig. 1). The second assumption was that wedge water was entrained trough the interface at the same rate throughout the extent of the interface upstream from 16th Avenue South Bridge.

The area of the interface is dependent upon its depth within the channel-the interface varies in width and length as it rises and declines in response to the tides. These variations were assumed to be uniform throughout the tidal cycle and the average position of the interface was used to calculate its area. For example, the average stage during the first study was 7.2 feet above MLLW and the average interface depth was 6 feet. The calculated interface area between East Marginal Way Bridge anc' 16th Avenue South Bridge at that stage and depth was 4.5 million square feet. Water in the bottom layer moved upstream during the study period at an average rate of $135 \mathrm{cfs}$. The entrainment 
across the interface is:

$$
\frac{135 \mathrm{cfs}}{4.5 \times 10^{6} \mathrm{ft}^{2}}=30 \times 10^{-6} \mathrm{cfs} \text { per } \mathrm{ft}^{2} .
$$

The resulting entrainment velocity $(E)$ has the dimensions, cfs per square foot, which reduce to feet per second (ft per sec). The following table shows the parameters determined for each of the salinity-velocity studies:

\begin{tabular}{|c|c|c|c|c|c|}
\hline Date & $\begin{array}{l}\text { Fresh- } \\
\text { water } \\
\text { inflow } \\
\text { (cfs) }\end{array}$ & $\begin{array}{l}\text { Bottom- } \\
\text { layer-flow } \\
\text { upstream } \\
(\mathrm{cfs})\end{array}$ & $\begin{array}{l}\text { Quasi-steady- } \\
\text { state period } \\
\text { (thousands } \\
\text { of sec) }\end{array}$ & $\begin{array}{l}\text { Area cf } \\
\text { interfane } \\
\text { (thousands } \\
\text { of sq } \mathrm{ft} \text { ) }\end{array}$ & $\begin{array}{l}\text { Entrainment } \\
\text { velocity, } E \\
\text { (millionths of } \\
\text { a cfs per sq } \mathrm{ft} \text { ) }\end{array}$ \\
\hline $\begin{array}{l}\text { Aug. } 28-29,1967 \ldots-- \\
\text { Sept. 6-7, } 1967, \ldots \\
\text { May } 22-23,1968 \ldots\end{array}$ & $\begin{array}{r}312 \\
312 \\
1,280\end{array}$ & $\begin{array}{l}135 \\
260 \\
180\end{array}$ & $\begin{array}{l}85.0 \\
83.4 \\
84.0\end{array}$ & $\begin{array}{l}4,500 \\
3,794 \\
1,827\end{array}$ & $\begin{array}{l}30 \\
69 \\
99\end{array}$ \\
\hline
\end{tabular}

Even though the first two studies were done at essentially the same fresh-water inflow, the calculated $E$ for the second study is approximately twice that of the first study. This is due primarily to the differences in the tidal exchange during the two studies. The study of August 1967 was done during a period of minimum tidal exchange and the study of September 1967 during a period of maximum tidal exchange. Apparently, the greater inflow and outflow in the study reach, produced by the larger tidal exchange, induced a more rapid upward movement of the wedge water. The study of May 1968 was done during a period of average tidal exchange; however, the fresh-water inflow was considerably larger and, as expected, the calculated $E$ : was greater.

\section{SUMMARY AND CONCLUSIONS}

Water mass and salt mass computed from field measurements on the stratified Duwamish River estuary have been shown to balance over selected quasi-steady-state periods (tidal cycles). The quasi-steady-state period is the period during which the water volume in a reach of the estuary is the same at the beginning as at the end of the period. Entrainment velocities for the movement of wedge water into the overriding upper layer have been calculated from mass-balance data.

The entrainment velocity for mixing of water from the saltwater wedge upward into the layer of fresher water was found to vary with fresh-water inflow and tidal-prism trickness. The range of the entrainment velocity was from $30 \times 1 \mathrm{C}^{-6} \mathrm{cfs}$ per sq ft to $99 \times 10^{-6} \mathrm{cfs}$ per sq ft between the salt-water wedge and the 
overlying layer at fresh-water-inflow rates of $312 \mathrm{cfs}$ and 1,280 $\mathrm{cfs}$, respectively. At a constant inflow rate of $312 \mathrm{cfs}$, the entrainment velocity increased from $30 \times 10^{-6}$ to $69 \times 10^{-6}$ cfs per sq $\mathrm{ft}$, for an increase in tidal-prism thickness from 10.2 to 20.6 feet.

The concept and values of the entrainment velocity developed here for the Duwamish River estuary are expected to greatly aid further quantitative studies of flow patterns and mixing in this estuary. The same approach should prove helpful also in studies of other stratified estuaries.

\section{SELECTED REFERENCES}

Fischer, H. B., 1968, Methods for predicting dispersion coefficients in natural streams, with applications to the lower reaches of the Green and Duwamish Rivers, Washington: U.S. Geol. Survey Prof. Paper 582-A, $27 \mathrm{p}$.

Isaac, G. W., Farris, G. D., and Gibbs, C. V., 1964, Special Duwamish River studies: Municipality of Metropolitan Seattle, Water Quality Sories 1, $37 \mathrm{p}$.

Pritchard, D. W., 1955, Estuarine circulation patterns: Am. Soc. Civil Eng. Proc., v. 81 , separate $717,11 \mathrm{p}$.

Santos, J. F., and Stoner, J. D., 1972, Physical, chemical, and biological aspects of the Duwamish River estuary, King County, Washington: U.S. Geol. Survey Water-Supply Paper 1873-C, 74 p.

Stoner, J. D., 1967, Prediction of salt-water intrusion in the Duwamish River estuary, King County, Washington, in Geological Survey researcl. 1967: U.S. Geol. Survey Prof. Paper 575-D, p. D253-D255.

U.S. Environmental Science Services Administration, 1967, Tide tables, high and low water predictions, west coast of North and South America, 1968: Washington, U.S. Govt. Printing Office, pub, annually.

Welch, E. B., 1968, Phytoplankton and related conditions in an enriched estuary: Water Pollution Control Federation Jour., v. 40, no. 10, p. 1711-1727.

1969, Factors initiating phytoplankton blooms and resulting ef ${ }^{c}$ ects on dissolved oxygen in Duwamish River estuary Seattle, Washington: U.S. Geol. Survey Water-Supply Paper 1873-A, 62 p.

Welch, E. B., and Isaac, G. W., 1967, Chlorophyll variation with tide and with plankton productivity in an estuary: Water Pollution Control Federation Jour., v. 39, no. 3, p. 360-366.

Williams, J. R., 1967, Movement and dispersion of fluorescent dye in the Duwamish River estuary, Washington, in Geological Survey rsearch, 1967: U.S. Geol. Survey Prof. Paper 575-B, p. B245-B249. 